\title{
The determination of the "true" property boundary in planned development: a Coasian analysis
}

\author{
Lawrence W. C. Lai ${ }^{1,2} \cdot$ Stephen N. G. Davies ${ }^{1} \cdot$ K. W. Chau ${ }^{1,2}$. \\ Ken S. T. Ching ${ }^{1} \cdot$ Mark H. Chua ${ }^{1} \cdot$ H. F. Leung ${ }^{1} \cdot$ Frank T. Lorne $^{1,2}$ \\ Received: 19 April 2018 / Accepted: 14 June 2018 / Published online: 27 June 2018 \\ (c) The Author(s) 2018
}

\begin{abstract}
This interdisciplinary paper, informed by research and practices in neo-institutional economics, property law and land surveying, is an exploratory account of the boundary as (a) the ontological foundation of private property in land and boundary dispute resolution, and (b) as a pre-contractual condition of any Coasian exchange of rights for planned urban development and space-relevant innovations. Under conditions of positive transaction costs according to the third Coase Theorem, with the help of real-life examples, the paper explains the choice of using the courts, instead of the market, as a means of resolving disputes over land boundaries. It does so in terms of two land surveying and three economic reasons. The surveying reasons are historical and cartographical. The economics reasons relate to the price level of land, the transaction costs of enforcing dispute resolutions and the externalities of land boundary determination.
\end{abstract}

\section{JEL Classification A12}

"Should the map represent physical or property boundaries?" "Property boundaries", says Sir John, "cannot, I submit, be drawn on a map, for property boundaries exist only in the mind. Property is a legal concept: its boundaries are national [sic] only. The imaginary line which in law separates one man's land from another is a mathematical two-dimensional line... it cannot be represented on a map". [as quoted by HLC (1933, pp. 108-109)].

\section{Introduction}

From the economics point of view, the importance of the property boundaries of land is much neglected. This neglect generally happens when cross-boundary issues like

\section{Lawrence W. C. Lai wclai@hku.hk}

Extended author information available on the last page of the article 
trespassing or nuisance are considered. Resolution of these by contract or private norms has been proposed as alternatives to government directions, assuming that either the boundaries in question is ex ante well defined in the case of a "Coasian bargain", or irrelevant in the case of some privately agreed norms in dealing with harms done to chattels on land but not to the land per se. That is fine in so far as no boundary alignment is contested in relation to the subject of the bargain (loss of cattle) or the locational idiosyncrasies of the land properties other than size or output. However, when the shape of land is called into dispute, land boundaries disputes cannot be ignored and this paper addresses why such disputes in an urban context are more likely than not settled by litigation.

The next section will paint a picture of the terms of art of land boundary disputes in land use research. This will be followed by an account of the reasons why the visible hands of the state and the law are often called into settle land boundary disputes in lieu of private settlement. Surveying and economic reasons are then offered to support this general view.

There is no claim, however, that the courts are always the best or correct solution in specific cases. However, that the courts are found to be so "popular" must be due to the fact that they adopt long-run efficient rules (Priest 1977) as well as that they are "self-correcting". 1

\section{Land boundary disputes in land use research}

Land is a hard issue in mainstream economics. Inspired by the work of Foldvary (2008), this paper is a neo-institutional economics attempt to dwell on one aspect of land as territorial space, i.e. space delineated by boundaries as the foundation for Schumpeterian innovations in spatially relevant things and institutional arrangements. Referencing neoclassical economist Carl Menger, Foldvary (2008, p. 90) drew attention to the "boundaried" nature of land: namely "Territorial space, the three dimensional surface of Earth, is fixed in supply on Earth..." By extension therefore, we infer that land is fixed not just in terms of quantity but "as to situation" and "has to be located in space" and that "there are economies of density and proximity associated with some locations".

As a matter of operation of a land system, as distinct from any sociological inquiry into the formation of boundaries as borders or zonal alignments, the vast and typically interdisciplinary body of research on property or land boundary dispute, as a major policy or legal reform arena, focuses mainly on the mechanism of dispute resolution, which is typically jurisdiction specific. Good examples are the work of Braimah (1987) on planning in Nigeria; Razin (1998) on planning against urban sprawl in Israel; Gough and Yankson (2000) on the land market in Ghana; Lombard (2015) on land reform in Mexico; Ubink and Quan (2008) on boundary dispute resolution procedures in Ghana; De Vries and Lewis (2009) in Namibia; Mbah (2009) in Cameroon; Kamruzzaman

\footnotetext{
1 As pointed out by Adams and Levine (2001), referencing Judge Cardozo (1921), "The law relies on logic and evidence in seeking justice. Furthermore, if the law is not viewed as a single case, but as a process, law is self-correcting to some degree over the long term. Legal rules that do not work and bad decisions are abandoned".
} 
and Baker (2013) in the Philippines; O'Brien and Prendergast (2013, 2014) in Ireland; Koo (2013) in England; and Sky (2013) on Norway.

An important branch of study is the effect of disputes. Adam et al. drew attention to land use conflicts. They pointed out that "conflicts in land uses and other natural resources are typically associated with opposing interests over the type of land use, limited access and use rights, unclear ownership and property rights, and the delineation of boundaries" (Adam et al. 2015, p. 1. Italics authors).

Yet another branch of scholarship is about the very nature of a boundary in relation to land property as property. Blomley, in an important treatise on land boundary determination by a court, which is confronted by the challenge of interpreting how a river, which changes in alignment, can be used as a boundary divider, argued that property is "a set of practices" rather than a thing on its own (Blomley 2008). He concluded that, "Property law, like any simplification, can be absurd. Yet to stop here is to risk ignoring the ways in which such absurdities organize the world for us in often brutally efficient and powerful ways" (Blomley 2008, p. 1840).

Blomley's contribution is important because, as argued by Lai (2015), Lai and Davies (2017) and Lai and Chau (2018), discussion of private property rights seldom touches on the boundary delineation of land as the ontological foundation of land as property. This is interesting since one of the characteristics of private property, like communal property, is exclusivity. Lai and Davies (2017) treated cadastral boundaries laid down in surveyor's primeval town plans (i.e. plans for town and farm lots allocated by grant or sale at colonization), as distinct from those map-based boundaries subsequently imposed by modern town planners under planning legislation as "zones", as insightfully analysed by Moroni and Lorini (2017), as both planned and planning boundaries.

Exclusivity concretized as access control to a piece of land of any size, from small parcel to whole country, makes no legal sense if its boundary is unknown or perhaps more importantly, uncertain. Disputes over land boundaries are disputes about property rights over what is disputed.

For systems of rights to land other than common property, ${ }^{2}$ land boundaries asserted and defended as a matter of physical expression-barriers and patrols enforcing control over this space not that, as it were-are essential features of de facto rights. Without such arrangements, a concept of exclusive property - mine not yours, keep out-is unlikely to arise. And if that starting point is absent, the move from de facto assertion to de jure claim cannot be made. We might instance here, if rather to one side of our narrower concern with private property, the present disputes between the People's Republic of China and India over territory in the high Himalaya. This is a classic dispute over claimed de facto rights that today depend, where arguably 300 years ago they did not, on a concept of exclusive property in this case bedeviled by the uncertainty of the location of a de jure boundary.

\footnotetext{
2 Save in a purely theoretical world in which all humanity constitutes a single "commons", even here as between "commons" the issue also arises. In true common property, there are strictly no boundaries. However, that common properties (like oceanic resources outside the outmost maritime economic zones effectively enforced) do exist means they are somehow bounded by boundaries of other exclusive zones.
} 
Once such claims are made, however, within the boundary asserted, there may be further boundaries or there may not be. In the latter case, as in communal property, there is no internal partitioning of rights. Only the "outer" boundary of "ours" exists.

For private property within a single system of privities however, systematic internal partitioning of land into units called "lots" or "parcels" within a national or regional boundary is a hallmark in spatial arrangements, which may be said to be the same as zoning, i.e. planned development in motion (Lai and Davies 2017).

Coase was an economist, who had a lot to say about private property in land (Lai and Chau 2018) and indeed land use planning. For example, his seminal paper, "The Problem of Social Cost" (Coase 1960), is based on a hypothetical land use story. The story can be interpreted as being about relocating a boundary fence ${ }^{3}$ that separates a cattle farm from a crop farm lot, so that the value of the cattle and crop product can be maximized. Coase's purpose is to show that in dealing with land use conflicts, private settlement by an exchange of de jure rights regarding the positioning of the boundary fence (Coasian exchange) can be a better alternative to zoning or a court battle. And it is so because it maximizes the joint value output of both plots of land rather than passively separating the two uses or punishing the wrongdoer under the prevailing law.

This story has become generalized as the Coase Theorem by George Stigler and was so recognized by Coase (1988, p. 157). The "invariant" version of this Theorem (Coase Theorem 1) holds that given: (a) transaction costs being zero and (b) "clearly defined property rights", then (x) the ways rights and liabilities are assigned (pattern of/design of law, institutions, etc.) WILL NOT affect (y) resource allocation. In other words, y is independent of and hence "invariant to" $\mathrm{x}$. The "optimality" version of this Theorem (Coase Theorem 2) holds that given (a) and (b), y will always be efficient. Under the assumed conditions of these theorems therefore, the "choice" with respect to the best way to resolve a conflict of interest or a dispute, whether by bureaucratic discretion (of an organization or "firm"), by contract (market) or by an independent umpire (arbitration or the courts) (i.e. any form of $\mathrm{x}$ ), would not affect resource outcomes y. One could say, one might as well flip a coin. Where the conditions do not hold, however, such "invariance" does not hold and each choice has a different resource outcome and efficiency implication.

As Lai (2007) explained, "clearly defined property rights" refer to clearly defined boundaries of the land parcels in the Coase story. In Coasian economic terms, the narrative of Adam et al. (2015) mentioned above means that an important assumption for the operation of the Coase Theorem is absent. Stigler's two theorems should be contrasted with a third theorem (Coase Theorem 3), first identified by Cheung from Coase (1959, p. 27) again as acknowledged by Coase (1988, p. 157). This holds that given zero transaction costs, "the delimitation of rights is an essential prelude for market transactions". Coase Theorem 3 is far less restrictive than Coase Theorem 1 or 2 , as "clearly defined property rights" or clearly defined boundaries are not required.

\footnotetext{
3 In his discussion, Coase talked about the erecting or not erecting a fence, rather than moving one, although that is an alternative that follows his logic in this passage: "Whether the cattle-raiser pays the farmer to leave the land uncultivated or himself rents the land by paying the land-owner an amount slightly greater than the farmer would pay (if the farmer was himself renting the land), the final result would be the same and would maximise the value of production" (Coase 1960, p. 6). See Lai (2007).
} 
Delimitation under Theorem 3 is not the same as a clear or full delineation of rights, which requires, generally, a well-entrenched Hayekian legal system in which there is respect for the rule of law and, specifically, accurate title and land boundary registration under Theorem 1 or 2 . This illuminates why in traditional societies, there was no need to delineate de jure land boundaries with great exactitude (Lai et al. 2015a, b; Lai and Davies 2017). The discussion that follows therefore assumes that costs of transactions are positive and thus the particular institutional solution to boundaries disputes is in focus.

\section{Land boundaries and Schumpeterian innovations}

At this juncture, there is a need to explain the relationship between boundaries and innovation. A property rights regime that is not common has a degree of exclusion. In spatial terms, this is measured by reference to the concept of a boundary across which outsiders may not move without permission. For a long time, the economic rationale for this has been articulated in terms of constraining rent dissipation by the use of a de jure boundary to effectively deny access to competitors. This can be physically defined by some natural features like a stream, or a man-made installation be it a net, a fence, a ditch or a wall, though of course it could also be purely notional or conventional. We are conscious here of early societies for which boundaries could be purely conventional, perhaps in addition signalled and reinforced by totems, as in cases of "taboo" and sacred spaces (Palmer 2016, Introduction and Ch.12).

This understanding is far too limited and its focus on exclusion easily lends support to an isolationist view of private property rather than an institutional arrangement for the promotion of production and trade, i.e. voluntary and mutually beneficial exchanges. The Coasian paradigm is fundamentally transaction oriented, assuming that the products are produced by the best technology according to the comparative advantage of the producer. In the real world, technology can progress due to innovations and where such innovations are land-related, "development" in a Schumpeterian scene comes into play.

Cattle farms, as exclusive properties, are not merely fenced off pockets where wild cattle roam and graze. Nor are crop plantations enclosures of tracts of wild crop in the wilderness. The social benefit of exclusion, made possible by the privatizing of land, is to allow the occupier the freedom from undue disturbance so that innovations may take place to improve and increase output. In this light, boundary delineation and management, as a feature of private property in Coasian terms, has a bearing on the upward shifts in the demand curve and/or downward shifts in the cost functions as measures of Schumpeterian innovations. The formal relationship between Coasian entitlements and Schumpeterian innovations was explained by Yu et al. (2000) using a phase diagram with a nonlinear (and thus non-neoclassical) production function, which was applied by Lai and Yu (2004) and Lai and Lorne (2006). Briefly, the assigning of exclusive rights (with various degrees of entitlements and obligations) enables attempts to innovate along a Schumpeterian production function, which allows possibilities of success and failure. In short, entitlement to land enables and encourages "betterment" of land, which goes beyond just excluding potential trespassers. Yu et al. 
(2000) explained that if a natural resource does not have a degree of exclusivity, innovation will not happen to that locality as all foresee rent dissipation. Therefore, exclusivity of locality can function to capture Schumpeterian rent. This is not Ricardian rent as traditionally understood. Lorne (2011), likewise, argued that the quality of land is as important as the quantity of land and that much property right creation can be enabled from perspectives outside the physical boundary of a property.

Gunther's attempt (2015) to explain the transience of the rise of Ming maritime power in terms of the ratio of coastline to boundary, referencing Schumpeterian growth as product improvement versus Coasian or Smithian market expansion, is a way of explicating how policing or enforcing boundaries without exchange is rather sterile.

As far as urban development is concerned, the pattern of private property lots as laid out by a town plan in the sense of Lai and Davies (2017) has an important bearing on innovation. The "town plan" here can refer to a "sub-division map" as mentioned in Coastal Property Associates v. Town of St. George, 1992 (Miller 2013) or a much older lot map or plan such as that for Swan River Settlement by Roe. As explained by Robert Home (1997) and Price (1995), these were the products of colonial surveyors. On the basis of their work, typically following a grid-iron pattern, we have the modern "town plans" or zoning maps [as explained in Lai and Davies (2017)] like that exhibited as Figure 1 in Moroni and Lorini (2017). Kiet (2010) indicated a possible support for this view in his account of the most common form of development of the traditional Arab city. For instance, a grid-iron pattern of urban development is argued to be the most permeable and flexible and so the most conducive to commercial growth compared with a loop or a cul-de-sac pattern, typical of the traditional Arab city, which stresses exclusivity by deterring or minimizing "through traffic".

The grid pattern is both easy to design and one through which it is easy to make initial land allocations. Land parcels are neatly unitized and, hence, reduce a lot of transaction costs in partitioning and assembly: they are more adaptable to expansion through duplication. Equally, units of land surrounded by existing public roads can be easily subdivided or combined to suit needs for densification. Scale matters in these options. A loop or cul-de-sac pattern is far more rigid and subsequent changes are harder.

The most famous privately zoned city, Houston, is predicated on a grid-iron pattern of subdivision.

\section{The firm and the law prevail over the market in conflict resolution}

Boundary disputes have a long history (Price 1955; Campbell 1996; Cuomo 2000). In recent years, there has been a huge surge in disputes as to the precise location of the common true boundary between lots, in spite of the promotion by professional and governmental bodies 4 of mediation or other modes of alternative dispute resolution (ADR) (see, for instance, O’Brien and Prendergast 2013, 2014; Koo 2013; Sky 2013). Scholars are aware that the commodification of land and the desire for "clearly defined property rights" in initial public offerings (IPO), due diligence, greed, etc., have added

\footnotetext{
${ }^{4}$ See, for instance, RICS.
} 
to the fuel. In terms of economic theory, the phenomenon can be summarized as one in which parties do NOT settle privately in a contractual manner via "The Market", according to the spirit of the land use conflict story used by Coase (1960). Instead, they seek the assistance of the courts, i.e. "The Law", which is an alternative to "The Firm" or "The Market". The title of Coase's (1988) book, a collection of past essays and reflections, on three "solutions" to disputes is entitled The Firm, The Market and The Law. This Coasian generalization does not imply that a court solution is always the most efficient outcome. However, any bad case will sooner or later be revoked or overruled by a more efficient decision. ${ }^{5}$ For the purpose of our analysis, it is not submitted that all boundary disputes are best decided by the courts. Rather, it is explained why the courts are a better alternative when dealing with urban land boundary disputes.

Translated into a Coasian language, the idea of Blomley (2008) referred to above might have conflated land property and property rights to land. The former is inputs/outputs and the latter social relations between persons with respect to land as either inputs or outputs. Blomley would thus agree that the law courts as an institution or the law as a "practice" have an effect: namely reducing the transaction costs of dealing with property rights to land.

According to Coase Theorem 1, the initial alignment of the property boundaries would not affect the land use mix, in terms of areas devoted to activities they are supposed to segregate, as parties could trade all or part of the land they own: that is, trade a movement of boundaries. That boundaries are tradable does not entail that therefore de jure land boundaries need not be clearly delineated ab initio. Whether such delineation is by custom, taboo, agreement or might and whether it is mapped or registered do not matter. What matters is that these boundaries are known and accepted de jure. Indeed, without certainty of boundaries, Coasian (contractual) exchange about their de facto (and economically efficient) location cannot commence.

In simple terms, under Coase Theorem 1, the resolution of boundary disputes is a pre-contractual process with a view to determining the de jure boundaries. Hence, the disputes cannot be resolved by mutual agreement.

One may think that there must be situations in which two landowners would like to settle a de jure common boundary confusion or ambiguity without a dispute or legal battle and would agree to the opinion of a third-party expert, say a land surveyor or a community leader. They trust that they can reach a "gentleman's solution" where for instance: (a) the parties inherit/acquire land knowing in advance that the de jure common land boundary is confusing and both parties are generous and/or disinterested and (b) they do not have the time or money to fight and a quick fix is preferred/required for something of greater importance/value. As these are not court stories, they are unreported and hence little known to outsiders.

However, the consensus of practitioners is that settlement outside the court over boundary disputes is rare. That is despite certain reported cases in which the legal costs of dispute settlement well exceed the values of the land involved. Why is it so hard for landowners to settle without the assistance of the government (a firm) court (the law)? There are both surveying and economic reasons for this, as discussed in the rest of this

\footnotetext{
5 See footnote 1 , ante.
} 
paper. In terms of Coasian logic, the task is to explain why, where transaction costs are positive, Coase Theorem 1, which presupposes the clearly delineated property boundaries (but zero transaction costs), is more applicable than Coase Theorem 3, which does not.

\section{Surveying reasons for non-market solutions in boundary disputes}

There are two surveying factors. The first is historical and the second map representational. The example under the first heading shows how the enormous costs of transactions prevent a market solution. Under the latter, we show the difficulties in removing boundary uncertainty in legal battles. The nature of these costs and the general relationship between litigation and land price are discussed in the next section.

\subsection{Boundary history}

The simple problem is of boundaries not having been set out in the same way for the same purpose since forever, i.e. a modern boundary is not, or not necessarily the same sort of thing as a customary boundary because the modern property market is not the same as the mode of transacting traditional property holdings (Lai and Davies 2017). Here, we may cite a real-life example from rural southern France. This marks the differences not only as between the world of subsistence mixed agriculture in the late nineteenth century and that of a mixture of subsidized monocultures and rapid retirement/vacation property development of a hundred years later, but also between the intimate communal mores of a small rural hamlet, the families of which had lived in the same place for a millennium, and the values of a mixed community of modern villagers with their educated children working all over France and the wider world, and with growing numbers of affluent newcomers from Paris and Northern Europe, who had retired and bought property there.

An old friend of one of the authors had bought a house and some land in a small southern French village in the foothills of the Albères massif. The transaction was completed as usual with the involvement of the local authorities and the requisite lawyers. All was well and he had acquired a hectare or so of rough French hill land on which stood a house and some small dépendences (garage, etc.) with scattered pine trees, native garrigue (scrub) and some clusters of cork oaks.

Some years later, he wished to reduce the size of his holding and sell off a part on which another dwelling could be built in order to bulk up his retirement funds. He began the process of getting the part he wished to sell duly surveyed and its boundaries registered, and the same for the new and reduced boundaries of his existing residence.

It turned out that about a century previously the paterfamiliases of two village families, who had each held several small but not often or even usually contiguous parcels of land on the plain and parcels on the hillside (as was common), had seen a way of making their respective working lives easier. In the case of two of the scattered parcels, one on the plains owned by A and one on the hillside owned by B, each was contiguous with the holdings of the other owner in the respective areas rather than 
their own. So the owners had decided between them to do a Coasian deal and had swapped. Party A consolidated his family holdings on the plain (vines and fruit trees) by incorporating the small parcel of Party B. Party B consolidated his family holdings on the hillside (rough grazing and cork oaks) by incorporating the small parcel of Party A. Both were happy and so things carried on. Figure 1 shows their de facto and de jure property boundaries.

It turned out, however, that that consensual arrangement had never been formalized with the authorities, so there had been no transfer of right. Everything had worked wonderfully whilst no one changed either the USE or the BOUNDARIES of the resulting aggregated parcels. However, over the years, especially in the years following France's "trente glorieuses" - the 30 years of rapid, post-war economic growth-agricultural use in the rough grazing/cork oak area on the hillside had given over to far higher value development for residential use. An incipient problem had lain lurking, invisible as long as the long-time agreed lot boundaries were unquestioned.

Initially, when the heirs of Party B had sold the property (the whole bounded area including the swapped part-let us call it X) to the first builder of the house that, subsequently, our friend had bought, the issue had remained buried because everyone had forgotten the "informal" arrangements the great grandfathers had agreed. Only when our friend wanted to subdivide and sell off, thus turning property $\mathrm{X}$ into property $\mathrm{X} 1$ and property $\mathrm{X} 2$, did the issue arise.

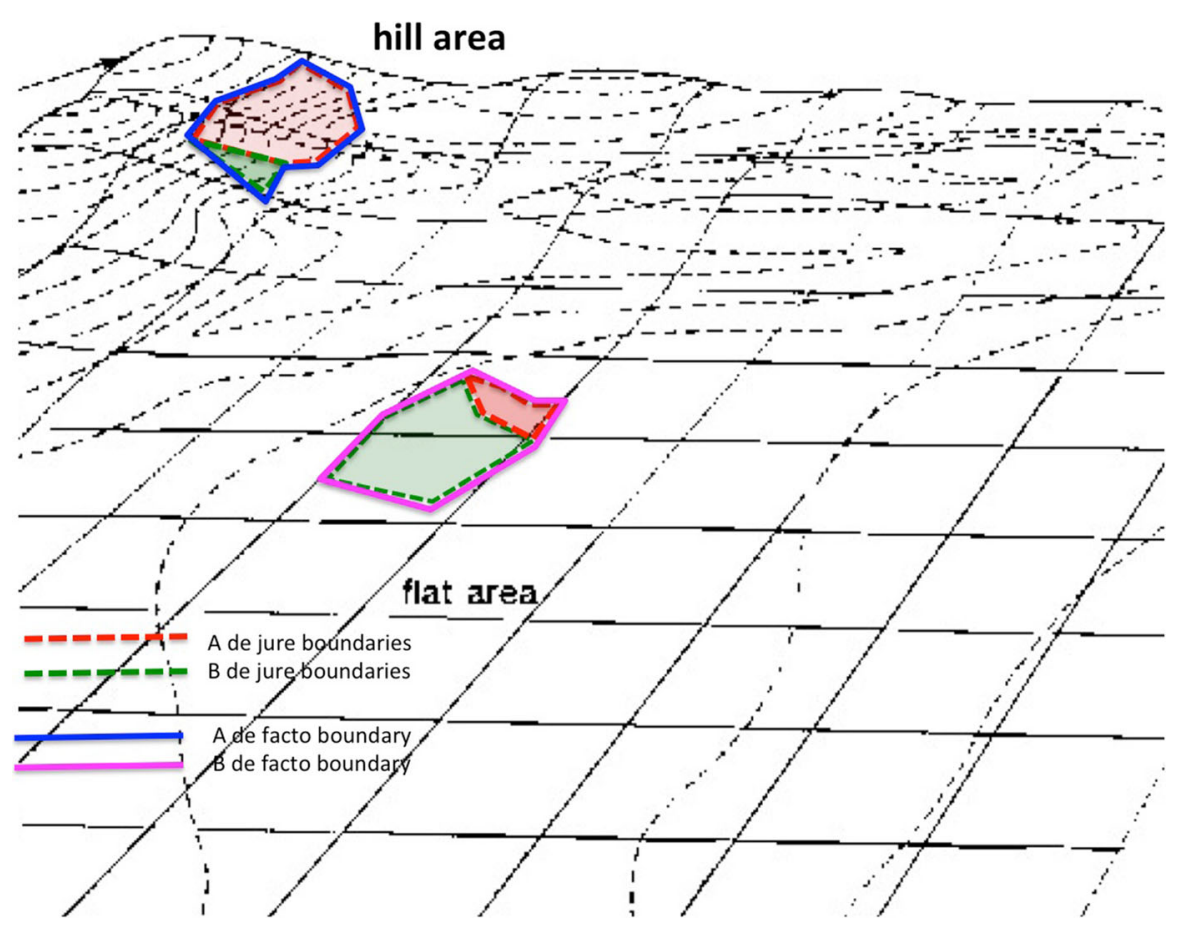

Fig. 1 Conceptual illustration of the case in France 
For it was then that he discovered, when he attempted to formalize his intent with the authorities, that within the boundaries of X2 lay land that he did not actually own but just had some sort of usufruct over. Of course, once the issue came up, the marked divergence in land value that had happened over the intervening years as between still agricultural plains land and the now extremely valuable residential hill land meant that the value relationship of the century old swap between valuable agricultural land and lower value rough hill land with cork oaks had reversed.

Naturally, the heirs of Party A were anxious to cash in on the enhanced value of "their" land, so wanted our friend to regularize the long-lasting informal arrangement by buying the bit of X2 he did not actually own. The money they wanted and the additional costs of re-survey, etc., would have wiped out the imagined gain for our friend, so he withdrew his plan.

Of course that did not make the issue go away, for there was now a clear ownership problem. Within our friend's property, though not enclosed by it, was a chunk that was not his. Given the costs involved in changing that state of affairs, he simply agreed that the heirs of Party A take back - that is, continue to "own"-their parcel. It was too small to build on and hence could not be developed on its own. Our friend in turn took back-i.e. continued to "own" - the equally valueless-on-its-own parcel on the plain. The existing de facto boundaries continued: a perfectly Coasian outcome (without much bargaining ${ }^{6}$ ), parties having considered the transaction costs of a formal exchange of de jure rights. There is no litigation or state direction needed to reach this equilibrium. A customary boundary setting practice, embedded invisibly within the land registrations systems of the modern rational state, had been confronted by that Weberian world and been found wanting.

\subsection{Boundary representation}

Second, and more technically, there is a scale/representation problem. If we quantify, what we are saying is that at two scales of roughly 1:2000 and 1:4000, a $1 \mathrm{~mm}$ (fine line) on the map represents, respectively, for example, a tract $1.98 \mathrm{~m}$ or $3.96 \mathrm{~m}$ wide on the ground and a 1-mm cadastral dot (a cadastre) represents a circle $1.98 \mathrm{~m}$ or $3.96 \mathrm{~m}$ in diameter. There are TWO possibilities ${ }^{7}$ here:

\footnotetext{
6 Coasian bargaining is often a loosely used term. See Lai et al. (2015a, b).

7 This is different to a boundary dispute between owners of two adjacent properties who disagree on where between them the dividing line lies. Neither is saying "this was once mine" with the other saying "indeed it was but you ceded it". Rather one is saying "the boundary dividing my property from yours is THERE and you have wrongly assumed it to be HERE, so you must return what you have illegally occupied". Here, a court could ask an authorized land surveyor (ALS) to establish by ArcGIS reconciliation and re-survey the swathe of land established as the boundary at a given scale (say the $3.96 \mathrm{~m}$ wide swathe of the 1898-1905 1:40,000 Hong Kong survey), get agreement from the owners on the swathe (that should cover all of the disputed land) and then simply make a Euclidean division supposing that to have been the intent of the original survey. That is, it can never have been the intent of a publicly undertaken survey, where no sort of corrupt collusion can be supposed or shown, to be wilfully inexact such that land holdings were inequitably reflected in the survey result. Nor should any property owner have a right at law to argue that she/he is entitled to exploit and benefit from inaccuracies inevitable given the shortcomings of earlier geodesy, surveying and mapping to her/his advantage and the disadvantage of her/his neighbour.
} 
(a) The possibility that arises if we assume radical indeterminacy. That is, the disputed boundary and cadastres may lie ANYWHERE within the margins of the boundary line/cadastral point so that potentially, for a 100-m long inter-property boundary, ALL of $100 \mathrm{~m} \times 1.98 \mathrm{~m}=198 \mathrm{~m}^{2}\left(\right.$ Or $\left.1.98 \mathrm{~m} \times 3.96 \mathrm{~m}=396 \mathrm{~m}^{2}\right)$ may belong to one or other owner and no one can decide which is the true answer by re-surveying, and hence the only solution is to get the court to decide.

(b) The "equitable" (Euclidean) supposition that the INTENT of ANY survey is to establish a "Euclidean" boundary between two properties. It follows that the accuracy of the survey should in principle be resolvable by a "median line"/"median point" solution.

A good reference problems of scale representation in maps can be found in Monmonier (2005).

It would be useful to look at some legal cases and see which way the courts lean. Do they in general assume that the answer has to be a category (a) answer? Or do they decide always on category (b)-type lines?

In Lam Pak Kau v. Yu Yuet Fat [1999] CACV 205/1999, the Appeal Court of Hong Kong, a common law jurisdiction from 1842, to the great headache of land surveyors, did not address either (a) or (b).

Based on the evidence adduced by the land surveyors for both parties, the Appeal Court found itself unable to decide whether there was trespassing by the building of a 250-mm-thick wall by the Defendant, and alleged by the Plaintiff to have been built along an old earth bund, which was the same as the "metes and bounds" of the agricultural lot boundary on a Demarcation District (DD) sheet produced in the early twentieth century.

The surveyor for the Plaintiff said he fixed the boundary between lots 970 and 991 by taking it as the mid-line of the bund. This is a (b)-type opinion. Lord Mayo agreed with the trial judge and cited his opinion about the bund:

That, of course, involves being able to fix the positions of each side of the bund. This bund is old. As I could see from the photographs, it has been subject to the normal wear and tear from erosion and human and animal activity that one would expect with what is simply a ditch excavated from the soil. I do not accept that a land surveyor, no matter how proficient, is able to say that this or that point fixes the outer limits of the bund with any great degree of accuracy. Nor, of course, is any land surveyor able to say that the bund was placed precisely on the boundary of two pieces of land. All he can do is saying that it follows approximately the line in plans, which are themselves incapable of providing great accuracy. There is no evidence that this placement was done with any anxiety to ensure that it was accurate to within one metre. History, common sense and the experience of the courts in dealing with this kind of case tell us otherwise. When these old bunds were erected, land in Hong Kong was cheap; no one would have been much concerned to ensure that the bunds were precisely placed. The fact that bunds were used at all as boundary markers, instead of some means of demarcation that was more precise, tells us this: by their very nature, they are imprecise instruments to mark a line. 
However, in a subsequent Court of First Instance case Liu Ma Cheung v. Liau Yin Fu [2007] HCA 181/2004, the recorder held that the DD sheet ${ }^{8}$ should be the starting point to determine boundaries in the New Territories. In short, the law does not necessarily add certainty in the case of either customary- or scale-dependent boundary disputes. The Law Reform Commission of Hong Kong (2014) recognized the situation.

4.11 The problems associated with the boundaries of the Block Crown Lease arose because, as a matter of law, the Block Crown Lease was granted as set out in the Demarcation District ("DD") sheet and not based on the actual occupation of the lot. It may perhaps be suggested that each lessee under the Block Crown Lease was in reality in actual occupation (of the land demised to him under it) in accordance with the existing land boundaries, and arguably, the Block Crown Lease should be construed by reference to the actual circumstances prevailing at the time it was executed. However, instead of the adoption of the usual phrase "for identification only", the term of the Block Crown Lease was drafted as if the plans were accurate and intended to reflect the real location of the piece of land. Under the current state of the law, the boundaries of the land grant under the Block Crown Lease were as set out in the DD sheets.

4.20 The fact is that the occupation situation at the time of DD survey had not been accurately reflected on the plan to meet the present day boundary requirement whereas Government and the court always refer to the DD sheet as the basis for dealing with land boundary matters. When applied to the subject issue, any existing occupation not conforming with the DD sheet boundary is treated as adverse possession and the boundary problem is resolved as an adverse possession case. (Underlining the authors)

What has happened is that there is a statutory need to have a professional survey of any land in the New Territories under the Land Survey Ordinance. Surveyors quickly found all kinds of discrepancies between actual occupation and DD lot boundaries, and hence title queries were and are raised about boundaries. This boundary matter can only be bypassed by adverse possession proceedings.

The recommendation of the Law Reform Commission, whilst dealing mainly with adverse possession in the New Territories of Hong Kong actually pertaining to boundary determination, was not a comprehensive re-survey but legislation, i.e. enacting a Land Titles Ordinance for statutory title registration along the line of the Torrens system. One wonders how registration without a correctly surveyed plan $^{9}$ can address the matter!

\section{Economics reasons for court battles in settling boundary disputes}

Nonetheless, however uncertain it can prove to be, the law remains the solution of last resort in boundary disputes. From an economic perspective, there are three reasons why court adjudication of disputes is superior. Each has an urban innovation connection.

\footnotetext{
8 See Cheng (2003), Leung et al. (2008), Yau (2008) and Hao (2009) on the use of this type of public document.

9 Land registration may not do away with land boundary disputes. See Barrett (1982).
} 


\subsection{Land price as a major determinant land boundary resolution methods}

There are many methods of land boundary definition and land boundary dispute resolution. Their outcomes could be determined by potential rent dissipation arising from the fuzziness in land boundaries and the transaction costs in defining and enforcing these boundaries. The former is a function of the per-unit value of the price of land as well as the total value of the parcels involved.

Land on its own is not normally productive; investment and innovations (e.g. by experimenting with ways of fertilizing and sowing seeds or forms of building structures on it, etc.) are necessary.

With underutilized and under-invested fuzzy zones, landowners have fear of losing their outputs or investments. This is a situation of rent dissipation. Higher land prices (\$/unit or total of site area) mean greater loss resulting from rent dissipation. Thus, situations like this call for clearer (more precise) delineation as well as a formal method of boundary dispute resolution.

There are also transaction costs in boundary delineation and boundary dispute resolution. The costs can escalate because of the conflictual nature of the dispute. Indeed, more costly methods will be used in high land price areas due to higher potential rent dissipation. Nevertheless, they will equal at the margin, a point advanced by Cheung (2014), who holds that transaction costs and rent dissipation are two sides of the same coin.

The above arguments do not imply that a higher frequency of formal means of boundary resolution will be observed in high land price urbanized areas for two reasons. First, in order to avoid the high cost of boundary dispute resolution by the courts or other formal means, clearer delineation of boundaries such as detailed land surveys, land lots in regular shapes (such as those according to a grid pattern) and detailed documentation of ownership, etc., will be used in high land price parcels, often in urban areas. Second, the high land price areas are usually the areas that were urbanized earlier. Any boundary dispute that could not be resolved by less costly informal means (Strahilevitz 2003) would be likely to have already been resolved by the courts or other formal means. Since court decisions are usually final and definitive, normally no further decision by a court is required for any boundary already adjudicated.

In rural areas, where land prices are lower, less costly methods are used to define land boundaries and resolve land boundary disputes. For example, in USA, some informal norms among ranchers and landowners were found by Ellickson (1991) to oust litigation (Fischel 1993). A similar resort to extrajudicial means can be found in China, where the boundaries of transacted rural or forestry land plots are usually vaguely defined with fuzzy boundaries (demarcated by metes and bounds, say stones, trees, etc.) and witnessed by villagers. Disputes over such loosely defined boundaries are rarely resolved by courts since the potential rent dissipation due to a fuzzy boundary is not high enough to justify the high litigation cost.

However, as rural land is converted into urban area in the urbanization process, the land value increases. This implies an increase in potential rent dissipation ${ }^{10}$ along the original fuzzy land boundaries. As a result, greater precision in land boundary

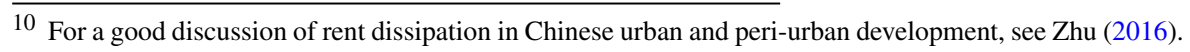




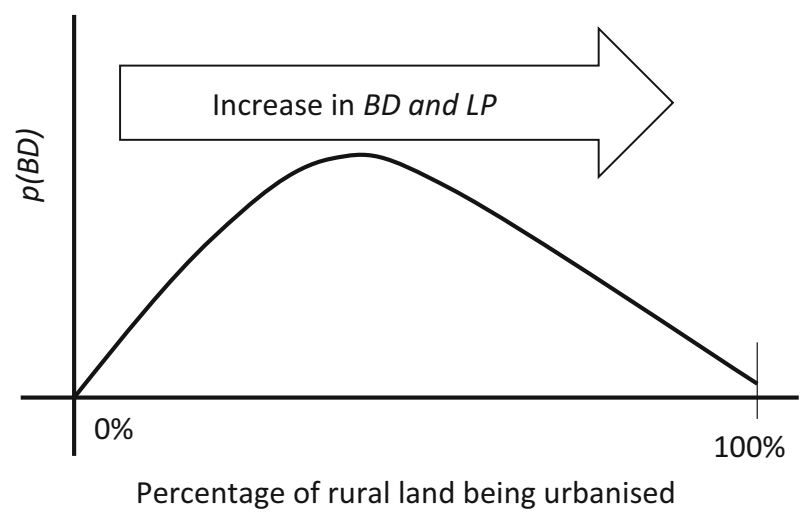

Fig. 2 Relationship between price of land and boundary disputes. The $x$-axis cannot be directly labelled as land price, as doing so would not yield a bell-shaped curve as drawn. The percentage of urbanized area is a proxy for average land prices. The presumption is that average land price increases as $\%$ of urbanized land increases

determination is needed to avoid rent dissipation of the two types mentioned. The dynamics of this need to be taken into consideration: dispute can often occur when the original fuzzy boundary is redefined with more precise instruments. As land prices increase, more disputes are likely to seek resolution from the courts or other formal institutions. Therefore, a higher demand for an authoritative delineation by the courts or other formal institutions is likely to be positively associated with the increase in land value (resulting from urbanization) rather than the absolute level of land value.

In sum, the chance of resolving land boundary disputes formally by authoritative institutions such as the courts is the lowest in predominantly rural and highly urbanized land. It is the transition from rural to urban use that sees land boundary dispute resolution by the courts as the most likely recourse.

A conceptualization of the above analysis is shown in Fig. 2. At the beginning of the transition where the percentage of urbanized land is low, the probability of formal resolution of any land boundary dispute by the courts, $p(B D)$, is low. But $p(B D)$ will start to increase due to an increase in land price $(L P)$ as more rural land is urbanized. As the number of land boundary disputes resolved by the courts $(B D)$ increases due to increases in land value, $p(B D)$ will start to decline since boundary disputes usually only need to be resolved once by the court. This will result in a maximum $p(B D)$ at some point during the urbanization process as depicted in Fig. 2.

Our model is reasonable and is empirically refutable. For instance, an Australian surveying school dissertation relates rising property prices to the prospect of a market for insuring the land surveyor (Oliver 2004). O'Brien and Prendergast (2013) wondered if falling property values increased disputes. For Hong Kong, Judge Cruden (2009) remarked:

Rapid increases in land values and growing awareness by owners and other persons having interests in land has led to parties to land transactions increasingly seeking legal assistance. Old errors are now more likely to be found and steps 


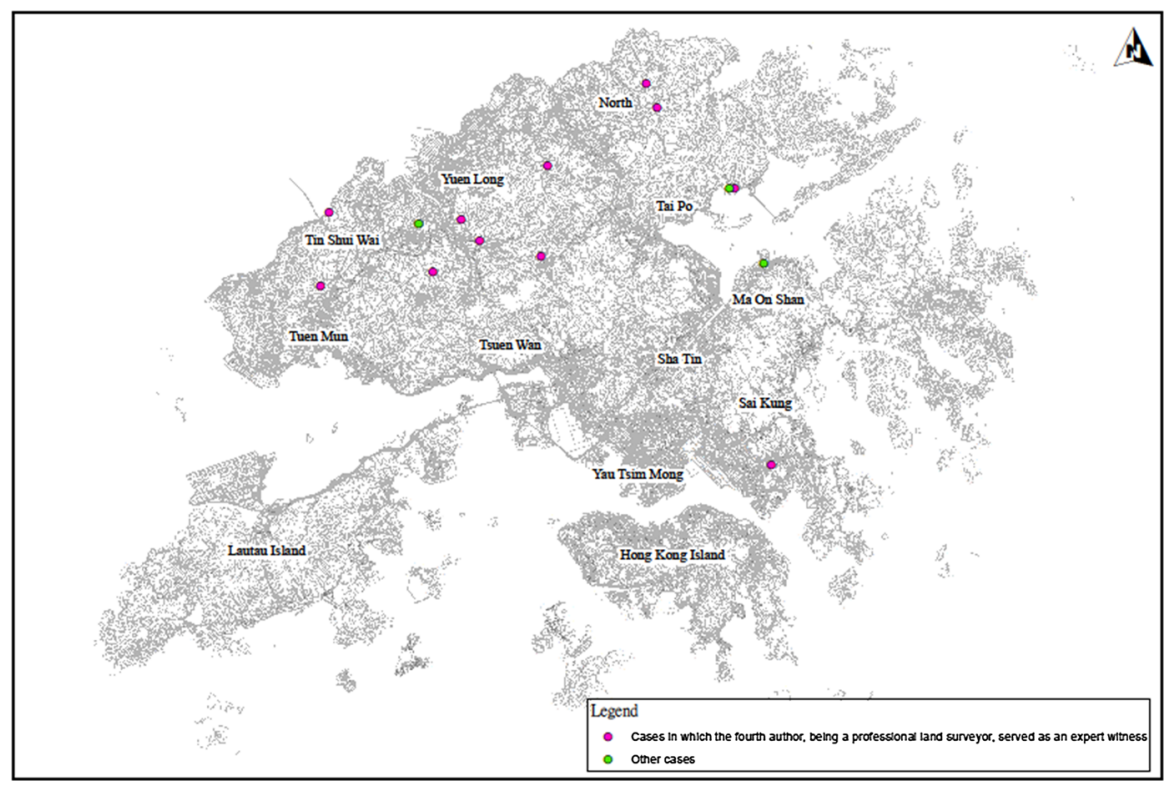

Fig. 3 Locations of land boundaries dispute cases

taken to have them corrected. Difficulties can still occur and the time is overdue for a major resurvey of the New Territories... (pp. 5-6)

The New Territories is a place of rapid increase in land values. However, it is beyond our resource limits to find statistical data to rigorously evaluate this deductive model, which will have to be the subject of another paper. However, the case of DD sheets in Hong Kong as discussed by the Law Reform Commission (2014) sheds some light on the validity of Fig. 2. The New Territories is rapidly urbanizing, and the focus of the Commission was on the private lots on this land mass of Hong Kong. Some idea may be gained from Fig. 3, which shows the locations of cases of boundary disputes in the court cases mentioned above as well as those handled by the fourth author as an expert witness. They are all in the suburbanizing rural areas, away from the urban new town cores in the New Territories. A rigorous test of the model would begin with plotting all boundary dispute/adverse possession cases onto a map with rent gradients.

Yin et al. (2013), tracing forest tenure and institutional reforms undertaken in China, which featured further devolving collective use rights, argued that "the ability of local users to make, monitor, and enforce contingent contracts-allowing individuals to agree to comply with the terms of an agreement if a specified proportion of their counterparts do the same-is important to successful implementation of decentralized forest management". (Yin et al. 2013, 831).

These individuals, according to a forestry lot document the authors inspected, are villagers who are assigned the rights to determine boundaries when a dispute arises. There is no reference to a court determination. In Coasian terminology, "The Firm", in the form of the village communal authority, is identified as the arbiter. 


\subsection{Land as a fixed asset or real property}

Land, being fixed in location, has a great transaction cost advantage in property rights protection if its boundaries are well defined. The respective claims of the parties in a dispute are also easily assessed once the boundary dispute is resolved by an authority (e.g. court). Therefore, it pays the landowners to resolve boundary disputes with expensive methods, as the determination will lower associated costs, notably the costs of assessing and enforcing compensation and specific performance. The cost of ADR may be lower compared with litigation but the associated costs subsequent to the decision may be much higher. This is a special characteristic of land.

For mobile/movable/personal properties, such as intellectual property (IP), settlement outside the court may be less costly as the court's ruling may not be easily enforced. (Eicher and García-Peñalosa 2008) Assessment of loss and of compensation over personal property by the court is also far more costly and inefficient. Real property has many unique advantages as it is difficult for it to "disappear" or run away, is easier to measure, and above all specific performance besides damages is available as a legal remedy. The last point is elaborated in the doctrine of interests and obligation "running with land", as explained below.

The doctrine of interests and obligation "running with land" in property law surely respects and reinforces the benefits of innovation in land property as a fixed asset, i.e. real property (a spatially bounded entity), and spatially relevant institutional arrangements. This common law doctrine regards corporeal stuff attached to land, otherwise footloose chattels, including any building or things fitted onto the former, as fixtures and hence an integral part of land as defined by its boundary. It confers upon frequent users and any lengthy (say 12 years) de facto exclusive occupier of land equitable rights against the de jure owner. And it also renders any agreement among landowners in respect of land, often in the form of "restrictive covenants", binding on all subsequent parties who deal in the land. The success of "non-zoning" or more accurately "private zoning" in Houston (Lai and Davies 2017) was due to such privately made covenants. Unlike informal norms discovered for rural Shasta County, these covenants are enforceable by the court.

\subsection{The impact of externalities in densely populated areas}

In a densely populated urban area, externalities are everywhere. Therefore, a boundary dispute may not only affect the value of the adjacent plots of land in a dispute but also those in more remote locations. The rights over a piece of land under dispute in connection with boundary delineation may have great value implications for land parcels not in dispute but under direct control of the parties involved. For example, a boundary dispute on a small piece of land may have serious repercussions on the accessibility to a much bigger piece of land if the access to it - a form of innovation by connecting two complementary uses, facilities or markets-must be gained through this small piece of land. Therefore, the high relative cost of resolving a dispute on a very small and apparently insignificant piece of land could well be rational if the values of other land lots are also taken into account. 
In fact, the legal system does sometimes take into account external effects. In the English Lands Tribunal Case Stokes v Cambridge Corporation (1962) 13 P. \& C.R. 77 , which involved a compulsory purchase of land, the tribunal held that the price of the access land, which was a piece of waste land and of almost no value originally, would be one-third of the increase in value of the land acquired attributable to the access.

This case is an example of the judiciary's recognition of how the value of a piece of land and the value of potential access land can be mutually affected if the latter can serve as an access to the former, thereby releasing its development potential.

\section{Discussion and conclusion: it is planned development after all}

This paper argues that in a world with positive transaction costs (in Coasian terms), the law and institutional arrangements, including legal and land registration systems, do matter and we can deduce that the court is a more efficient arbiter for disputes than the market. Furthermore, the material cause that the court must establish to settle a dispute is the boundary, which is the ontological foundation of private property in land and is a pre-contractual condition in boundary disputes.

Two surveying and three economic reasons, with implications for urban innovations, have been given:

First, boundaries are temporal matters and long outlast even the lifetime of the human beings who initially instituted them. The example above gives a good illustration of how boundaries existing chronologically earlier are not necessarily superseded in the current state of affairs. Pragmatically speaking, the law-or at least its fundamental principles - should transcend time for it to be practically useful for "precedents". Fundamental laws that are mutable through time obviously will not be sustainable. The courts, supposedly the vanguard and interpreter of the law, must carry the same burden, else there would exist too much uncertainty and risk for them to be able to contribute to a sustainable solution. This parallel role of the courts with respect to a historically transcendent law could be taken into account in understanding why it could be a more efficient means in settling disputes.

Second, the concept of dimensionless lines, although abstractions of the human mind and conceptually applied to the real, dimensioned world, is subject also to human limitation, error, imprecision and vice. In settlement cases where scale/representational problems are involved, it becomes more practical and less costly to allow some instituted-hopefully competent - authority to decide on and enforce the matter. Many times, a simple third party is not enough, it has to be a respected body with the authority and the competence to affirm the truthfulness of those conceptual lines, understood from a reasonable man's point of view, as determinants of the real boundaries of the property, or at the very least as justly setting reasonable reference guidelines.

Third, the precision and tolerance accuracy with respect to boundaries-whether before, during or after sale_-depend much on the unit value per measure of the land. The demand for exactitude in any land boundary, or "lot boundary", in modern land development is a derived demand. Property rights to land for urban development, in the modern property market, are concretized and valued in terms of real estate devel- 
opment, which is three-dimensional with a planimetrically accurate two-dimensional horizontal site plan entailing certitude in boundary alignment. Although litigation is quite costly, courts in a society where the rule of law prevails are nevertheless recognized as viable and legitimate platforms for solving the present and future status of the real property-if a dispute is eventually resolved - given that the realized value is worth all the court processes and expenses.

Fourth, the mere fact that land is fixed in a location (except when the force of nature modifies it), within the context of specific socio-enviro-cultural rules and institutions, makes the boundaries more fundamental. The owner cannot take the object owned into the confines and protection of his or her own realm but has to go to it. The nature of unenclosed, undeveloped land being easily open to the view and to the intrusion of the public further entails investment on the part of the owner. This high cost demands the safeguard of a local expert protector, which is more conveniently in a form of a court.

Fifth, in principle in a bilateral market transaction, the court can be accepted as a more authoritative overseeing and farseeing entity compared to any third party. Negative externalities can be lessened more in this manner. It does not mean the courts are a perfect steward of the common good, but at least the courts offer a reasonable approximation to it.

In summary, from a Coasian perspective, the courts should be the more efficient means for resolving land disputes than the market. The surveying reasons are the historical perduring and the cartographical limitation of boundaries. The economics reasons relate to the price level of land, the transaction costs of enforcing dispute resolutions, especially in real property, and the externalities of land boundary determination.

The nature of boundary dispute resolution, being contingent on rising urban land prices and the blurring of the urban-rural boundary, something condemned by Abercrombie (Matless 1993), is conditioned, if not also driven by modern planning intervention. Planning applications invariably require declaration of landownership status and demarcation of the land and the layout of the development on a "plan". So the courts are in a sense working in tandem with the state as a super firm in ordering development. After all, Coase did entitle his work The Firm, The Market And The Law, not The Firm, The Market OR The Law.

Acknowledgements The authors are most grateful to the useful comments by two anonymous referees on the manuscript. All faults remain the authors.

Open Access This article is distributed under the terms of the Creative Commons Attribution 4.0 International License (http://creativecommons.org/licenses/by/4.0/), which permits unrestricted use, distribution, and reproduction in any medium, provided you give appropriate credit to the original author(s) and the source, provide a link to the Creative Commons license, and indicate if changes were made.

\section{List of Cases}

Coastal Property Associates, Inc. v. Town of St. George, 1992

Lam Pak Kau v. Yu Yuet Fat [1999] CACV 205/1999

Liu Ma Cheung v Liau Yin Fu [2007] HCA 181/2004

Stokes v. Cambridge Corporation [1962] 13 P. \& C.R. 77 


\section{References}

Adam YO, Pretzsch J, Darr D (2015) Land use conflicts in Central Sudan: perception and local coping mechanisms. Land Use Policy 42:1-6

Adams TB, Levine BM (2001) Junk science, environmental risk, and very low detection levels in NPDES permits. Mo Environ Law Policy Rev 8(2):48-58

Barrett MM (1982) UK cadastral plans and the law: the significance of Lee v Barrey. Surv Rev 26(205):337-342

Blomley N (2008) Simplification is complicated: property, nature, and the rivers of law. Environ Plan A 40(8):1825-1842

Braimah AA (1987) Planning practice in Bendal State, Nigeria. Habitat Int 11(2):19-31

Campbell B (1996) Shaping the rural environment: surveyors in ancient Rome. J Rom Stud 86:74-99

Cardozo BN (1921) The nature of legal process. Yale University Press, New Haven

Cheng NF (2003) An implementation of boundary security to land registration system in HKSAR. Unpublished $\mathrm{PhD}$ dissertation, Hong Kong Polytechnic University

Cheung SNS (2014) China's economic system. Man Econ 1(1):1-49

Coase RH (1959) The Federal Communications Commission. J Law Econ 2:1-40

Coase RH (1960) The problem of social cost. J Law Econ 3:1-44

Coase RH (1988) The firm, the market and the law. University of Chicago Press, Chicago

Cruden GN (2009) Land compensation and valuation law in Hong Kong. Lexis Nexis, Hong Kong

Cuomo S (2000) Divide and rule: Frontinus and Roman land-surveying. Stud Hist Philos Sci Part A 31(2):189-202

De Vries W, Lewis J (2009) Are urban land tenure regulations in namibia the solution or the problem? Land Use Policy 26(4):1116-1127

Eicher T, García-Peñalosa C (2008) Endogenous strength of intellectual property rights: implications for economic development and growth. Eur Econ Rev 2(2):237-258

Ellickson RC (1991) Order without law: how neighbors settle disputes. Harvard University Press, Cambridge

Fischel WA (1993) Book review on order without law: how neighbors settle disputes by Robert C. Ellickson. Land Econ 69(1):113-115

Foldvary FE (2008) The marginalists who confronted land. Am J Econ Sociol 67(1):89-117

Gough KV, Yankson PW (2000) Land markets in African cities: the case of peri-urban Accra, Ghana. Urban Stud 37(13):2485-2500

Gunther M (2015) The Chinese maritime frontier: $10^{\text {th }}-16^{\text {th }}$ century. Master thesis, School of Economics and Management, Lund University

Hao J (2009) The re-establishment of old schedule lot boundaries in Wu Kai Sha Village. Unpublished PhD dissertation, Department of Land Surveying and Geo-Informatics, Hong Kong Polytechnic University

HLC (1933) Review of Conference of Empire Survey Officers 1931: report of proceedings. Emp Surv Rev 2(8):108-120

Home R (1997) Of planting and planning: the making of British colonial cities. E \& FN Spon, London

Kiet A (2010) Arab culture and urban form. Focus 7(1):36-45

Kamruzzaman M, Baker D (2013) Will the application of spatial multi criteria evaluation technique enhance the quality of decision-making to resolve boundary conflicts in the Philippines? Land Use Policy $34: 11-26$

Lai LWC (2007) 'The problem of social cost'; the Coase theorem and externality explained: using simple diagrams and examples to illustrate the role of land use planning in tackling externalities. Town Planning Review 78(3):335-368

Lai LWC (2015) 'Where to draw the line?' That is a land use planning question for the land surveyor and the town planner. Land Use Policy 42:619-627

Lai LWC, Chau KW (2018) A reinterpretation of Coase's land monopoly model: locational specificity and the betterment potential of land as de jure and de facto property. Prog Plan. https://doi.org/10.1016/j. progress.2018.01.002

Lai LWC, Davies SNG (2017) A Coasian boundary inquiry on zoning and property rights: lot and zone boundaries and transaction costs. Prog Plan 118:1-28

Lai LWC, Lorne FT (2006) The Coase theorem and planning for sustainable development. Town Plan Rev $77(1): 41-73$

Lai LWC, Yu BT (2004) Implementing sustainable development: institutional features, Encyclopaedia of life support systems (EOLSS). UNESCO, Paris 
Lai LWC, Chau KW, Lorne FT (2015a) 'Unclear' initial delineation of property boundaries and the third Coase theorem. Land Use Policy 47:273-281

Lai LWC, Davies SNS, Lorne FT (2015b) Creation of property rights in planning by contract and edict: beyond Coasian bargaining in private planning. Plan Theory 15(4):418-434

Lai LWC, Hung H, Chua MH (2017) Maps as Coasian coordination tools: heritage conservation and map representation. Land Use Policy 62:280-289

Law Reform Commission of Hong Kong (2014) Report: adverse possession, Hong Kong. http://www.hkr eform.gov.hk

Leung SC, Sham TPF, Tang CHW (2008) The reality versus the legality of the demarcation district sheets. Surv Built Environ 19(1):26-37

Lombard M (2015) Land conflict in peri-urban areas: exploring the effects of land reform on informal settlement in Mexico. Urban Stud 53(13):2700-2720

Lorne FT (2011) A framework for understanding property rights creation: quantity vs. quality dimensions of properties. Surv Built Environ 21(1):8-26

Matless D (1993) Appropriate geography: Patrick Abercrombie and the energy of the world. J Des Hist 6(3): $167-178$

Mbah EM (2009) Disruptive colonial boundaries and attempts to resolve land/boundary disputes in the grasslands of Bamenda, Cameroon. Afr J Confl Resolut 9(3):11-32

Miller SR (2013) The visual and the law of cities. Pace Law Rev 33(1):183-233

Monmonier M (2005) Lying with maps. Stat Sci 20(3):215-222

Moroni S, Lorini G (2017) Graphic rules in planning: a critical exploration of normative drawings starting from zoning maps and form-based codes. Plan Theory 16(3):318-338

O'Brien D, Prendergast WP (2013) Why are property boundary disputes increasing in Ireland? In: International postgraduate research conference, University of Salford, Manchester, 8-10 Apr 2013

O'Brien D, Prendergast WP (2014) Proposed guidebook on established case law for land surveyors on property boundaries. Surv Rev 46(334):58-65

Oliver AJ (2004) Relevance of identification surveys in NSW conveyancing. Bachelor of Surveying dissertation, University of Southern Queensland (Toowoomba)

Palmer A (2016) Noongar people, Noongar land: the resilience of aboriginal culture in the south west of Western Australia. Aboriginal Studies Press, Canberra

Price DJ (1955) Medieval land surveying and topographical maps. Geogr J 121(1):1-7

Price ET (1995) Dividing the land: early American beginnings of our private property mosaic. University of Chicago Press, Chicago

Priest GL (1977) The common law process and the selection of efficient rules. J Leg Stud 6(1):65-82

Koo AKC (2013) Proving property boundaries. Convey Prop Lawyer 77:395-402

Razin E (1998) Policies to control urban sprawl: planning regulations or changes in the 'rules of the game'? Urban Stud 35(2):321-340

RICS. A clear, impartial guide to boundary disputes. www.rics.org/consumerguides. Accessed 5 Oct 2016

Sky PK (2013) Mediation in boundary disputes. http://theboundary.no/ep_tmp/files/37906934549f0d5992 4754.pdf

Strahilevitz LJ (2003) Social norms from close-knit groups to loose-knit groups. Univ Chica Law Rev 70(1):359-372

Ubink JM, Quan JF (2008) How to combine tradition and modernity? Regulating customary land management in Ghana. Land Use Policy 25(2):198-213

Yau FC (2008) A study on determination of lot boundaries in Hong Kong Special Administrative Region. Unpublished $\mathrm{PhD}$ dissertation, Hong Kong Polytechnic University

Yin R, Yao S, Huo X (2013) China's forest tenure reform and institutional change in the new century: what has been implemented and what remains to be pursued? Land Use Policy 30(1):825-833

Yu BT, Shaw D, Fu T, Lai LWC (2000) Property rights and contractual approach to sustainable development. Environ Econ Policy Stud 3(3):291-309

Zhu Z (2016) The impact of land rent seeking and dissipation during institutional transition on China's urbanization. J Urban Aff. https://doi.org/10.1177/1078087416646206 


\section{Affiliations}

Lawrence W. C. Lai ${ }^{1,2}$. Stephen N. G. Davies ${ }^{1}$ - K. W. Chau ${ }^{1,2}$.

Ken S. T. Ching ${ }^{1} \cdot$ Mark H. Chua $^{1} \cdot$ H. F. Leung ${ }^{1}$ - Frank T. Lorne ${ }^{1,2}$

Stephen N. G. Davies

stephen.davies79@gmail.com

K. W. Chau

hrrbckw@hku.hk

Ken S. T. Ching

keland@biznetvigator.com

Mark H. Chua

mhansley.chua@gmail.com

H. F. Leung

hfleung@hku.hk

Frank T. Lorne

florne@nyit.edu

1 Department of Real Estate and Construction, University of Hong Kong, Pokfulam Road, Hong Kong, China

2 Ronald Coase Centre for Property Rights Research, University of Hong Kong, Pokfulam Road, Hong Kong, China 